\title{
Socioeconomic factors associated with tobacco smoking among adult males in Sri Lanka
}

\author{
Hiranya Nilakshi Fernando', Imaesha Thilini Pradeepika Wimaladasa', Anjali Nimaya Sathkoralage', \\ Ashani Nisansala Ariyadasa ${ }^{1}$, Chathurika Udeni ${ }^{1}$, Lahiru Sandaruwan Galgamuwa ${ }^{2 *}$, Prasanna Herath ${ }^{1}$ and \\ Nishantha Kumarasinghe ${ }^{3}$
}

\begin{abstract}
Background: Tobacco smoking is considered as a major public health issue worldwide. Reduction of tobacco usage has been one of the main government policies in Sri Lanka and the price of cigarettes has been raised several times in the last few years. The purpose of this study was to evaluate the socioeconomic factors associated with tobacco smoking among adult males in Sri Lanka.

Methods: A study was conducted in Gampaha district in Sri Lanka recruiting 365 tobacco smoking people and their spouses. Data regarding tobacco smoking were obtained using an interviewer administrated questionnaire.

Results: Frequency of tobacco smoking was negatively associated with the improvement of educational levels. Employment, monthly income, influence of friends, smoking frequency before price increment, weekly expenditure for smoking, low educational level and the age of first smoking exposure was significantly associated with tobacco smoking among smokers. According to the spouses, smoking frequency before price increment, weekly expenditure of the husbands of smoking and influence of friends, number on smoking friends, spouse's employment and husband's monthly income were factors associated with tobacco smoking of their husbands. In addition, smoking at home, at work places and at friend's houses was significant with the frequency of daily smoking.

Conclusions: Increasing the price of tobacco products has no significant impact on smoking behaviors in Sri Lanka. The need for essential strategies to educate and motivate the smokers to stop smoking is required. Primary care health workers might play a major role in motivating smokers to quit smoking.
\end{abstract}

Keywords: Tobacco, Taxation, Smoking

\section{Background}

Smoking of tobacco products occurs occasionally or habitually as a consequence of a physical addiction to some chemicals, primarily the highly addictive psychoactive ingredients such as nicotine [1]. More than 1 billion people are smoking globally and $80 \%$ of them are living in low and middle income countries [2, 3]. In Sri Lanka, it is recorded as $29.9 \%$ individuals are currently smoking [4].

Tobacco is the second major cause of adult mortality in the world. The number is expected to exceed 8 million

\footnotetext{
*Correspondence: lahiruahs@yahoo.com

${ }^{2}$ Department of Medical Laboratory Sciences, Faculty of Health Sciences, The Open University of Sri Lanka, Colombo, Sri Lanka

Full list of author information is available at the end of the article
}

deaths by 2030 , with approximately $70 \%$ of these deaths are occurring in developing countries [5]. Smokers also face a much greater risk of premature death than nonsmokers [6]. In addition, smoking tends to cause accelerated age related cognitive decline associated with the loss of grey matter in the brain [7].

Tobacco smoking increases the risk of developing chronic obstructive pulmonary diseases (COPD), particularly in high and middle income countries [4]. Frequency of smoking is increasing as economies develop, but it is also linked to poverty and poor education [4]. Breathing unhealthy air is a risk factor for most respiratory diseases [8]. The key factors for preventing such diseases are reduction of tobacco smoking and the improvement of air

(c) The Author(s). 2019 Open Access This article is distributed under the terms of the Creative Commons Attribution 4.0 International License (http://creativecommons.org/licenses/by/4.0/), which permits unrestricted use, distribution, and reproduction in any medium, provided you give appropriate credit to the original author(s) and the source, provide a link to the Creative Commons license, and indicate if changes were made. The Creative Commons Public Domain Dedication waiver (http://creativecommons.org/publicdomain/zero/1.0/) applies to the data made available in this article, unless otherwise stated. 
quality, which includes a reduction in second-hand or passive tobacco smoke inhalation.

The government of Sri Lanka has introduced many anti-smoking programs to reduce the consumption of tobacco products among Sri Lankans. Prohibition of sales and promotion of tobacco products to minors (below 21 years), prohibition of advertising, promotion and sponsorship, compulsory health warnings on cigarette packets, theatres and television programs and prohibition of smoking in public places are the important provisions to reduce the usage of tobacco products in Sri Lanka. In addition, the policy of price increase aiming to discourage the consumption of cigarettes was introduced to the country after 2010 .

The marital relationship directly influences to the health behaviors of the wife and husband [9]. Many studies have documented that married people have better health and healthy behaviors than the unmarried $[10,11]$. However, sparse information is available to assess the awareness of socioeconomic factors of tobacco smoking in Sri Lanka. Therefore, this study was designed to evaluate the association of socioeconomic factors with tobacco smoking among adult males and the awareness of spouses about smoking of their husbands in Sri Lanka.

\section{Methods}

\section{Study setting/population}

This study was conducted in Gampaha district from June to December 2017. Gampaha District spreads the area of $1387 \mathrm{~km}^{2}$ and is located in the western province of Sri Lanka adjacent to the commercial capital, Colombo. The population of Gampaha district was nearly 2.3 million in 2017. This district has been divided into 15 Medical offices of Health (MOH) divisions. Out of them, 10 divisions were selected randomly using SPSS statistical software for this research namely; Gampaha, Mirigama, Divulapitiya, Aththanagalla, Negombo, Kelaniya, Ragama, Minuwangoda, Biyagama and Ja-Ela.

The sample population was randomly selected from 10 $\mathrm{MOH}$ areas in Gampaha district. The data were collected with the support of regional health officers such as Public Health Nursing Sisters (PHNS), Public Health Midwives (PHM), Public Health Inspectors (PHI) and Grama Niladari (GN) officers in the selected areas. They assisted to coordinate this study to recruit married couples and was explained the objectives and the procedure of the study.

\section{Sampling and sample size}

The sample size was calculated using the equation of $n=\mathrm{z}^{2} \mathrm{p}(1-\mathrm{p}) / \mathrm{d}^{2}$ where $n=$ sample size, $\mathrm{z}=1.96$; critical value of specified confidence at $95 \%$ confidence interval, $p=$ probable estimate of proportion of the prevalence of tobacco smoking among males in Sri Lanka (29.9\%) [4] and $\mathrm{d}=5 \%$ of absolute error. Minimal sample size was calculated as 330. In addition, 10\% sampling error was added to minimize irresponsible and recording errors and the final sample size was 365 .

Then, 365 married couples were selected from the selected $\mathrm{MOH}$ divisions. The number of couples in each division was considered according to voter registration of each $\mathrm{MOH}$ division. Then written consent forms were obtained from selected smoking adult males to participate in the study. Males, who were aged below 18 years and unmarried, were excluded. In addition, spouses of the selected smoking males were included for the study.

\section{Data collection}

Information on tobacco consumption was obtained using an interviewer administered questionnaire. Before the initiation of each interview, the interviewer explained the objectives of the study. After obtaining informed written consents, data was collected from male smokers and their spouses at their residences. The questionnaire consisted of a mixture of qualitative and quantitative questions. Male questionnaire consisted with 33 questions regarding socio demographic data, smoking history and smoking behavior; economic factors contributed to tobacco smoking and preferred places of tobacco smoking. Female questionnaire consisted with 35 questions regarding socio demographic data, awareness of duration, influence and types of husband's smoking, economic factors contributed to husband's tobacco smoking, spouses attitudes regarding tobacco smoking, spouses awareness of husband's preferred smoking places. The questionnaire was initially developed in English and then translated into the native languages in Sri Lankans (Sinhala and Tamil).

\section{Statistical analysis}

Ages of the participants were categorized into three groups; 19-39, 40-59, 60-79 years old. Educational attainment was classified into three groups; who were completed ordinary level or below ordinary level (11 years or low school education), completed advanced level (13 years of school education) and completed Diploma or Degree level (more than 13 years of school education).

All data was entered into a Microsoft Excel 2010 data sheet. Data was analyzed by descriptive statistical analyzing methods using SPSS Version 23. Male smokers were divided into two groups as daily smokers and not daily smokers depending on their frequency of smoking. Multivariate logistic regression analysis was applied to assess the association of socioeconomic factors with tobacco smoking. Chi square test was used to determine the preferred places for smoking among smokers. $P$ value less than 0.05 was considered as significant. 


\section{Results}

\section{General characteristics}

Three hundred and sixty five married male smokers (mean age $43.3 \pm 11.5$ years) and their spouses (mean age $40.2 \pm 11.1$ years) were participated to the study. Majority of the participants educated up to the general certificate of education (GCE) ordinary level. Majority of the males were employed (98.9\%) while 69\% females were unemployed. Most of males (44.9\%) and females (54.9\%) were employed less than 10 years. Mean monthly income for males was 48,170 $\pm 60,053$ LKR (Sri Lankan Rupees) (267.6 \pm 333.6 USD) and for females was $34,796.50 \pm 32,351$ LKR $(193.3 \pm 179.7$ USD).

\section{Smoking patterns and behaviors of smokers and awareness of their spouses}

Mean age of the first experience of smoking was 16.7 years. Interestingly, two thirds of smokers had more than 10 smoking friends. Majority of smokers (83.2\%) used premade cigarettes and "Gold leaf" was the commonest brand of cigarette among these participants. Majority of the male participants (69.9\%) were daily smokers before increasing the price in 2016 and majority of the study participants (93.4\%) were aware of the new price. However, 69.3\% participants smoked daily after increasing the price. In addition, 59.2\% of participants reported that they smoked similar frequency of tobacco products per day before and after price increasing. More than $80 \%$ of smokers were not used any alternatives instead of tobacco products after raising the price of tobacco products.

More than two third of spouses were aware of smoking of their husbands before marriage. According to $92.1 \%$ of spouses, the influence of friends is very important factor to tend them for smoking. Cigarette is the most common tobacco product and Gold leaf is the commonest brand of cigarettes in Sri Lanka.

More than half of male participants prefer to smoke at home, at friend's house, at social event and other places like parties. However, in 59\% of spouse's opinion, home is the preferred place for smoking for their husbands. Majority of both male (84.9\%) and female (84.4\%) participants expressed that they don't smoke at public places.

In accordance with the awareness of spouses, more than half of $(56.7 \%)$ their husbands were smoking daily before price increment. Out of them, $66.3 \%$ continued to smoke daily after increasing the price of tobacco products. Majority of the spouses (86.6\%) reported that their husbands smoke less than 10 cigarettes per day after the price increment. More than half of female participants were not happy about the proportion of income spends for household activities. According to half of spouses, smoking is the main reason for a low proportion of income available for house hold activities.
Associations of socioeconomic factors with tobacco smoking among adult males

Multivariate logistic regression analysis identified that frequency of smoking before and after price increment, weekly expenditure for smoking, employment of the smoker, monthly income, influence of friends, low educational level and the age of first smoking exposure was significantly associated with tobacco smoking (Table 1). In addition, smoking at home, at work places and at friend's houses were also significant factors with current rate of smoking per day (Table 2).

\section{Associations of socioeconomic factors with tobacco smoking according to the awareness of spouses}

According to spouses imaginations, frequency of smoking before price increasement, money spend for smoking, proportion spend for smoking from his monthly income, cigarette type tobacco products, low monthly income, monthly income not enough for household activities, friend's influence for smoking, number of smoking friends, spouse's employment and education level and husband's monthly income number of cigarettes smoke per day before and after price increment were significantly associated with tobacco products of their husbands (Table 3).

Awareness of husband's preferred place for smoking friend's house, smoking at home, at work place, functions and public places were significantly associated with tobacco smoking (Table 4).

\section{Discussion}

In the present study, the educational level of spouses' was inversely proportional to the husband's smoking frequency. It was assumed that higher educational level of the spouses may have more tendencies to distract their husbands from smoking. Mayer et al., (2004) was reported that smoking was significantly lower in men with secondary and higher education compared to those with only primary education [12].

Secondary or higher education may affect to prevent the initiation of smoking or to reduce the frequency of smoking via better awareness about potential health hazards of smoking [13]. Individuals with low level of education have a higher probability to become smokers and higher rates of smoking per day [14]. In the present study, the education is an important predictor of smoking than income. In such circumstances the educational level related differences in smoking might be larger than those related to income or employment. However, Laaksonen et al., 2005 reported that socioeconomic indicators showed a strong association found between socioeconomic indicators and smoking and it was increased gradually from the higher to the lower socioeconomic groups, irrespectively to the indicator they used [15]. 
Table 1 Association of socioeconomic factors with tobacco smoking (Male)

\begin{tabular}{|c|c|c|c|c|c|c|}
\hline \multirow[t]{2}{*}{ Variable } & \multirow[t]{2}{*}{ Categories } & \multicolumn{2}{|c|}{ Current Frequency } & \multirow[t]{2}{*}{ OR } & \multirow[t]{2}{*}{$95 \% \mathrm{Cl}$} & \multirow[t]{2}{*}{$p$ value } \\
\hline & & Daily (\%) & Not daily (\%) & & & \\
\hline \multirow[t]{3}{*}{ Age (Years) } & 19-39 & 99 (38.8) & $52(47.3)$ & 1 & & \\
\hline & $40-59$ & $125(49.0)$ & $44(40.0)$ & 0.462 & $0.125-1.711$ & 0.248 \\
\hline & $60-79$ & $31(12.2)$ & $14(12.7)$ & 0.355 & $0.108-1.160$ & 0.086 \\
\hline \multirow[t]{3}{*}{ Educational level } & Up to Ordinary level & $159(62.3)$ & $52(47.3)$ & 1 & & \\
\hline & Up to Advanced level & $66(25.9)$ & $35(31.8)$ & 0.377 & $0.117-1.216$ & 0.103 \\
\hline & Diploma/Degree & $30(11.8)$ & $23(20.9)$ & 0.140 & $0.036-0.427$ & 0.041 \\
\hline \multirow[t]{3}{*}{ Employment } & Government & $119(45.8)$ & $55(50.0)$ & 1 & & \\
\hline & Private & $70(26.1)$ & $33(30.0)$ & 2.431 & $0.862-6.855$ & 0.093 \\
\hline & Self-employment & $66(26.1)$ & $22(20.0)$ & 5.036 & $1.632-15.545$ & 0.005 \\
\hline \multirow{4}{*}{$\begin{array}{l}\text { Duration of } \\
\text { employment (Years) }\end{array}$} & $<1$ & $17(6.7)$ & $5(4.5)$ & 1 & & \\
\hline & $1-10$ & $107(41.9)$ & $56(50.9)$ & 0.204 & $0.025-1.637$ & 0.134 \\
\hline & $11-20$ & $82(32.2)$ & $32(29.1)$ & 1.263 & $0.404-3.949$ & 0.688 \\
\hline & $>20$ & $49(19.2)$ & $17(15.5)$ & 1.164 & $0.364-3.719$ & 0.798 \\
\hline \multirow[t]{4}{*}{ Monthly income (LKR) } & $<10,000(<55.5$ USD $)$ & $12(4.7)$ & $2(1.8)$ & 1 & $0.462-1.855$ & \\
\hline & 10,001-50,000 (55.5-277.7 USD) & $174(68.2)$ & $68(61.8)$ & 0.302 & & 0.419 \\
\hline & 50,001-100,000 (277.7-555.5USD) & $61(23.9)$ & $34(30.9)$ & 0.081 & $0.012-0.568$ & 0.011 \\
\hline & $>100,000$ (> 555.5 USD) & $8(3.1)$ & $6(5.5)$ & 0.106 & $0.016-0.724$ & 0.022 \\
\hline \multirow{2}{*}{$\begin{array}{l}\text { First exposure of } \\
\text { smoking (Years old) }\end{array}$} & $<18$ & $134(52.5)$ & $44(40.0)$ & 1 & & \\
\hline & $>18$ & $121(47.5)$ & $66(60.0)$ & 0.418 & $0.188-0.933$ & 0.033 \\
\hline \multirow[t]{3}{*}{ Influence to smoking } & Self-preferred & $62(24.3)$ & $24(30.8)$ & 1 & & \\
\hline & Friends & $163(63.9)$ & $62(28.0)$ & 0.120 & $0.030-0.484$ & 0.003 \\
\hline & Others & $30(11.8)$ & $23(43.2)$ & 0.219 & $0.071-0.670$ & 0.008 \\
\hline \multirow[t]{4}{*}{ Current form of tobacco } & Cigarette & $172(67.5)$ & $86(78.1)$ & 1 & & \\
\hline & Cigar & $6(2.3)$ & $1(0.9)$ & 1.470 & $0.577-3.741$ & 0.419 \\
\hline & Beedi & $17(6.7)$ & $3(2.7)$ & 0.254 & $0.010-6.742$ & 0.413 \\
\hline & Others & $60(23.5)$ & $20(18.2)$ & 0.362 & $0.057-2.311$ & 0.283 \\
\hline \multirow[t]{3}{*}{ Form of cigarette } & Premade cigarette & $140(81.2)$ & $73(84.5)$ & 1 & & \\
\hline & Roll on your own & $23(13.3)$ & $10(9.1)$ & 0.506 & $0.104-2.465$ & 0.399 \\
\hline & Both & $9(5.5)$ & $3(5.4)$ & 0.552 & $0.206-1.435$ & 0.106 \\
\hline \multirow[t]{3}{*}{ Types of cigarette } & Gold leaf & $80(46.6)$ & $36(42.0)$ & 1 & & \\
\hline & Bristol & $30(17.6)$ & $13(15.2)$ & 1.018 & $0.429-2.419$ & 0.970 \\
\hline & Others & $62(35.7)$ & $37(40.2)$ & 0.420 & $0.139-1.272$ & 0.125 \\
\hline \multirow[t]{3}{*}{ Past frequency } & Daily & $223(87.4)$ & $33(30.0)$ & 1 & & \\
\hline & Not daily & $23(9.0)$ & $72(65.5)$ & 0.273 & $0.049-1.509$ & 0.137 \\
\hline & Never & $9(3.5)$ & $5(4.5)$ & 10.396 & $1.779-60.868$ & 0.009 \\
\hline \multirow[t]{4}{*}{ Weekly expenditure (LKR) } & $<250(<1.4$ USD $)$ & $54(21.2)$ & $60(23.5)$ & 1 & & \\
\hline & 250-500 (1.4-2.8 USD) & $92(36.0)$ & $23(20.9)$ & 16.705 & $4.446-6.765$ & $<0.001$ \\
\hline & 501-1000 (2.8-5.6 USD) & $46(18.0)$ & $21(19.1)$ & 1.993 & $0.555-7.155$ & 0.290 \\
\hline & $>1000$ (> 5.6 USD) & $63(24.7)$ & $6(5.5)$ & 0.704 & $0.669-10.927$ & 0.163 \\
\hline \multirow[t]{4}{*}{ Number of Smoking friends } & None & $11(4.3)$ & $3(2.7)$ & 1 & & \\
\hline & $<10$ & 78 (30.6) & $44(40.0)$ & 0.091 & $0.011-0.775$ & 0.028 \\
\hline & $>10$ & $43(16.7)$ & 14 (12.7) & 0.431 & $0.130-1.429$ & 0.169 \\
\hline & Everyone & $65(25.5)$ & 19 (17.2) & 0.346 & $0.083-1.445$ & 0.146 \\
\hline
\end{tabular}


Table 1 Association of socioeconomic factors with tobacco smoking (Male) (Continued)

\begin{tabular}{|c|c|c|c|c|c|c|}
\hline \multirow[t]{2}{*}{ Variable } & \multirow[t]{2}{*}{ Categories } & \multicolumn{2}{|c|}{ Current Frequency } & \multirow[t]{2}{*}{ OR } & \multirow[t]{2}{*}{$95 \% \mathrm{Cl}$} & \multirow[t]{2}{*}{$p$ value } \\
\hline & & Daily (\%) & Not daily (\%) & & & \\
\hline & Not sure & $58(22.7)$ & $30(27.2)$ & 0.594 & $0.161-2.190$ & 0.435 \\
\hline \multirow[t]{2}{*}{ Awareness of new price } & Yes & $239(93.7)$ & $103(93.6)$ & 1 & & \\
\hline & No & $16(6.3)$ & $7(6.4)$ & 1.297 & $0.304-5.538$ & 0.726 \\
\hline \multirow[t]{3}{*}{ Amount after new price } & Same amount & $149(58.5)$ & $67(61.8)$ & 1 & & \\
\hline & $<10$ & 95 (37.2) & $43(39.2)$ & 1.485 & $0.109-20.282$ & 0.767 \\
\hline & $>10$ & $8(3.2)$ & $0(0.0)$ & 0.889 & $0.203-41.050$ & 0.433 \\
\hline
\end{tabular}

Adults in low SES can easily buy tobacco products due to tobacco products are readily available, thus increases the risk of bad health consequences $[16,17]$. Low socioeconomic condition strongly related to continuation of smoking among adult males, particularly in developing countries [18-20]. Stressful life may strongly affect for the initiation and the higher rates of continuation of smoking. In addition, unemployed adults and adolescents may tend to high continuation rates of smoking due to the effect of low income and high stress condition [21]. Less access to adequate health care and financial difficulties increase their stress levels, making them more susceptible to involve health risks such as smoking [13].

In the present study, the majority of individuals initiated smoking before the age of 18 years old has a high probability to become daily smokers. Similarly studies in Malaysia and China reported that the majority of male smokers imitated smoking by the age of 18 [22, 23]. Similarly a study in Ghana reported that $76.3 \%$ of smokers started smoking at age between 16 and 20 years and $80.5 \%$ were influenced by friends [24]. Several studies revealed that peer influence is one of the major

Table 2 Preferred places for smoking (males)

\begin{tabular}{lllll}
\hline Places & Category & \multicolumn{2}{l}{ Current Frequency } & p value \\
\cline { 3 - 4 } & & Daily (\%) & Not daily (\%) & \\
\hline Home & Yes & $150(59.3)$ & $44(39.3)$ & $<0.001$ \\
\multirow{2}{*}{ Work place } & No & $103(40.7)$ & $68(60.7)$ & \\
\multirow{2}{*}{ Friend's house } & Yes & $147(58.1)$ & $32(28.6)$ & $<0.001$ \\
& No & $106(41.9)$ & $80(71.4)$ & \\
Functions & No & $109(46.9)$ & $46(41.1)$ & 0.005 \\
& Yes & $134(53.0)$ & $69(58.9)$ & \\
Public places & No & $119(47.0)$ & $43(38.4)$ & 0.125 \\
& Yes & $40(15.8)$ & $15(13.4)$ & 0.552 \\
Other & No & $213(84.2)$ & $97(86.6)$ & \\
& Yes & $46(18.2)$ & $20(17.9)$ & 0.941 \\
& No & $207(81.8)$ & $92(82.1)$ & \\
\hline
\end{tabular}

causes of smoking and often victims started smoking at a very early age in their life $[25,26]$.

Cigarette is the prominent form of tobacco product in Sri Lanka and the brand of commonest cigarette type was Gold leaf. However, small number of smokers used more than one type of tobacco products such as Cigarette, Beedi, White Beedi, Pipes and Cigar. Beedi is a hand-rolled, leaf- wrapped cigarette, often with sweet flavors. Cigar is a tightly rolled bundle of tobacco wrapped in leaf tobacco. Since cigarettes in Sri Lanka are now close to the most expensive in Asia, more and more adult smokers aged more than 50 years old are turning to smoking Beedis. In the present study, small numbers of male participants use more than one type of premade cigarettes, namely Redrose, Marlboro, Benson, Dunhill, Capton, Sportsman, Three roses and Hedges. Similarly, cigarettes and hand-rolled tobacco were the most commonly consumed tobacco product in Malaysia, Philippines (97.8\%) and Thailand (64.9\%) male smokers [22, 27, 28]. However, cigarettes were less popular in India $(43.1 \%)$ and compare to Sri Lanka where handrolled tobaccos were commonly used [29].

According to majority of spouses, peer influence has been a major impact on both initiation and maintenance of tobacco smoking habits of their husbands. According to spouses, majority of husband's used premade cigarettes and the commonest type of cigarette was Gold leaf. Bristol is the second mostly using a type of cigarette. The majority of daily smokers in Sri Lanka were not bounded to any one form or a brand of tobacco and they used more than one form at different times.

In the present study, the average number of cigarettes smoked by the study respondents was 12.3 cigarettes per day. This average number of cigarettes is more than the 11.3 cigarettes per day reported in Philippines [27] and less than 13.5 and 14.3 cigarettes per day reported in China and Vietnam, respectively [30, 31]. Raising the price of cigarette through increasing taxes is a more effective tobacco control policy measure for reducing smoking behavior among young adults and persons of low socioeconomic status [32]. 
Table 3 Association of socioeconomic factors with tobacco smoking (Female)

\begin{tabular}{|c|c|c|c|c|c|c|}
\hline \multirow[t]{2}{*}{ Variable } & \multirow[t]{2}{*}{ Category } & \multicolumn{2}{|c|}{ Current Frequency of husbands } & \multirow[t]{2}{*}{ OR } & \multirow[t]{2}{*}{$95 \% \mathrm{Cl}$} & \multirow[t]{2}{*}{$p$ value } \\
\hline & & Daily (\%) & Not daily (\%) & & & \\
\hline \multirow[t]{3}{*}{ Age (Years) } & 19-39 & $131(50.0)$ & $63(61.2)$ & 1 & & \\
\hline & $40-59$ & $111(42.4)$ & $34(33.0)$ & 1.250 & $0.280-5.577$ & 0.770 \\
\hline & $60-79$ & $20(7.6)$ & $6(5.8)$ & 0.786 & $0.179-3.458$ & 0.750 \\
\hline \multirow[t]{3}{*}{ Educational level } & Up to ordinary level & $146(55.7)$ & $43(41.7)$ & 1 & & \\
\hline & Up to advanced level & $89(34.0)$ & 39 (37.9) & 0.562 & $0.215-1.474$ & 0.242 \\
\hline & Diploma / Degree & $27(10.3)$ & $21(20.3)$ & 0.283 & $0.060-0.793$ & 0.048 \\
\hline \multirow[t]{4}{*}{ Employment } & Government & $27(10.3)$ & $25(24.3)$ & 1 & & \\
\hline & Private & $27(10.3)$ & $13(12.6)$ & 2.653 & $1.053-6.687$ & 0.039 \\
\hline & Self-employment & $21(8.0)$ & $7(6.8)$ & 3.098 & $1.171-8.195$ & 0.023 \\
\hline & Unemployment & $187(71.4)$ & $58(56.3)$ & 1.400 & $0.435-4.503$ & 0.573 \\
\hline \multirow[t]{3}{*}{ Initiation of smoke } & Before marriage & $177(67.6)$ & $65(63.1)$ & 1 & & \\
\hline & After marriage & $30(11.5)$ & $14(13.5)$ & 0.728 & $0.334-1.587$ & 0.425 \\
\hline & Don't know & $55(21.0)$ & $23(22.3)$ & 0.593 & $0.195-1.808$ & 0.358 \\
\hline \multirow[t]{2}{*}{ Current form of tobacco } & Cigarettes & $186(71.0)$ & $92(89.3)$ & 1 & & \\
\hline & Beedi & $76(29.0)$ & $11(10.7)$ & 0.868 & $0.277-2.720$ & 0.808 \\
\hline \multirow[t]{3}{*}{ Type/s of premade cigarettes } & Gold leaf & $109(58.4)$ & $57(62.1)$ & 1 & & \\
\hline & Bristol & $31(16.4)$ & $17(18.4)$ & 1.078 & $0.482-2.413$ & 0.855 \\
\hline & Others & $46(25.2)$ & $18(19.4)$ & 0.875 & $0.303-2.528$ & 0.805 \\
\hline \multirow[t]{2}{*}{ Past smoking } & Daily & $228(87.0)$ & $35(34.0)$ & 1 & & \\
\hline & Not daily & $34(13.0)$ & $68(66.0)$ & 0.058 & $0.029-0.115$ & $<0.001$ \\
\hline \multirow[t]{3}{*}{ Amount of spend per week } & $<250$ & $27(10.3)$ & $10(9.7)$ & 1 & & \\
\hline & $250-500$ & $191(72.9)$ & $65(63.1)$ & 0.895 & $0.316-2.532$ & 0.834 \\
\hline & $501-1000$ & $44(16.8)$ & $28(27.2)$ & 1.217 & $0.338-4.385$ & 0.764 \\
\hline \multirow[t]{3}{*}{ Husbands monthly income } & $<50,000$ & $145(55.3)$ & $58(56.3)$ & 1 & & \\
\hline & $50,001-100,000$ & $59(22.5)$ & $17(16.5)$ & 0.320 & $0.064-1.592$ & 0.164 \\
\hline & $>100,000$ & $58(22.1)$ & $28(27.2)$ & 0.469 & $0.223-0.987$ & 0.046 \\
\hline \multirow{3}{*}{$\begin{array}{l}\text { Proportion spend for smoking } \\
\text { from household expenditure }\end{array}$} & $1 / 4$ & $70(26.7)$ & $20(19.4)$ & 1 & & \\
\hline & $1 / 2$ & $114(43.5)$ & $54(52.4)$ & 0.859 & $0.400-1.845$ & 0.697 \\
\hline & Other & $78(29.8)$ & $29(28.2)$ & 1.210 & $0.468-3.129$ & 0.694 \\
\hline \multirow[t]{2}{*}{ Number of smoking friends } & $>10$ & $202(77.1)$ & $63(61.2)$ & 1 & & \\
\hline & $<10$ & $60(22.9)$ & $40(38.8)$ & 0.336 & $0.171-0.662$ & 0.002 \\
\hline \multirow[t]{2}{*}{ Friend's influence } & Yes & $246(93.9)$ & $90(87.3)$ & 1 & & \\
\hline & No & $16(6.1)$ & $13(12.7)$ & 0.172 & $0.057-0.523$ & 0.002 \\
\hline \multirow{2}{*}{$\begin{array}{l}\text { Amount of Cigarettes smoke } \\
\text { per day after price increment }\end{array}$} & $<10$ & $221(84.3)$ & $95(92.2)$ & 1 & & \\
\hline & $>10$ & $41(15.7)$ & $8(7.8)$ & 3.313 & $1.003-11.059$ & 0.049 \\
\hline
\end{tabular}

Two thirds of female participants reported that husbands have continued similar rate of smoking daily even after the price increment. Home, at a friend's house, at parties and at working places were the preferred places for smoking. Home seems like is the safest for our respondents as they might have more freedom. Majority of females mentioned that their husbands preferred to smoke at home. Similarly, in Jordan, one third of husbands from their population smoke inside of their homes [33].

Majority of both participants mentioned only the "home" as preferred place. It reveals that the spouses' awareness of husband's habits and behaviors outside of the house is in a low rate. However, in the present study, lower rate of males preferred to smoke in public places. Only $20 \%$ of spouses reported that their husbands prefer 
Table 4 Awareness of spouses about preferred places for smoking of their husbands

\begin{tabular}{llllll}
\hline Places & Category & \multicolumn{2}{l}{ Current Frequency } & p value \\
\cline { 3 - 5 } & & Daily & Not daily & Don't know & \\
\hline Home & Yes & $167(69.0)$ & $33(39.8)$ & $15(37.5)$ & $<0.001$ \\
& No & $75(31.0)$ & $50(60.2)$ & $25(62.5)$ & \\
Work place & Yes & $113(46.7)$ & $18(21.7)$ & $10(25.0)$ & $<0.001$ \\
& No & $129(53.3)$ & $65(78.3)$ & $30(75.0)$ & \\
Friend house & Yes & $117(48.3)$ & $25(30.1)$ & $17(42.5)$ & 0.015 \\
& No & $125(51.7)$ & $58(69.9)$ & $23(57.5)$ & \\
Functions & Yes & $111(45.9)$ & $45(54.2)$ & $21(52.5)$ & 0.023 \\
& No & $131(54.1)$ & $38(45.8)$ & $19(47.5)$ & \\
Public place & Yes & $39(16.1)$ & $7(8.4)$ & $11(27.5)$ & 0.023 \\
& No & $203(83.9)$ & $76(91.6)$ & $29(72.5)$ & \\
Others & Yes & $46(19.0)$ & $18(21.7)$ & $9(22.5)$ & 0.797 \\
& No & $196(81.0)$ & $65(78.3)$ & $31(77.5)$ & \\
\hline
\end{tabular}

to smoke in public places. This confirms that they have a certain amount of control of their smoking patterns and behaviors in the public places. This could be a result of the law from NATA Act 2016 "Smoking in public was prohibited in Sri Lanka" or may be the changed attitudes of society.

Majority of the smokers were apparently seen the warning signs of cigarette packages, but those smokers cannot read, have seen the pictorial warnings. Government legislation of warning signs on cigarette packages ( $80 \%$ from the cigarette package) was not very much affected by the reduction of tobacco smoking. Tobacco taxation, passed on to consumers in the form of higher cigarette prices, has been recognized as one of the most effective population-based strategies for decreasing the frequency of tobacco smoking. Tobacco taxes can benefit smokers who quit, reduce the overall consumption of tobacco, and put smoking cessation on their radar of those who continue to smoke. Increased taxes also have a positive impact on non-smokers by reducing their exposure to second-hand smoke. Increased tobacco taxes, passed on to consumers in the form of higher cigarette prices, provide an economic disincentive to those who smoke or may be contemplating smoking [32]. However, due to high price of branded cigarettes might influence the smokers to find some alternatives which might be more dangerous.

Exposure to the anti-smoking media messages using multimedia is another important measure to motivate smokers to quit. Therefore, the programs on health hazards from smoking and control of tobacco products in community level, at workplaces and schools could effect on reducing health disparities.

\section{Conclusions}

In Sri Lanka, the price increment policy has not affected to change tobacco smoking behaviors. Most of male smokers in this study did not reduce the number of cigarettes after the price increase may be because of their addiction to cigarettes. This study strongly supports that increasing the prices of tobacco products via taxations is not a powerful strategy for achieving the reduction in the rate of the smoking behavior Sri Lankan population. Awareness programs on smoking in community level should be commenced targeting all strata of the population and making them aware about the harmful effects and disease conditions of tobacco use. Anti-smoking campaigns must also be initiated in a broad manner, specially targeting the smoking population as well as their family. Media campaigns for anti-smoking campaigns are also very effective.

\section{Abbreviations}

COPD: Chronic obstructive pulmonary diseases; GN: Grama Niladhari officer; LKR: Sri Lankan Rupees; LMIC: Low and middle-income countries; MOH: Medical officers of Health; NATA: National Authority on Tobacco and Alcohol; PHI: Public Health Inspector; PHM: Public Health Midwife; PHNS: Public Health Nursing Sister; USD: United States Dollars; WHO: World health organization

\section{Acknowledgements}

We would like to express our deepest gratitude to the male and female individuals who participated in this study. It is our pleasure to thank the management, medical authorities and other health care workers in Gampaha district for their cooperation for this study. Our sincere thanks also go to the academic and non- academic staff of the Department of Nursing and Midwifery, Faculty of Allied Health Sciences, Genera Sir John Kotelawala Defence University, Sri Lanka for their continuous support.

\section{Authors' contributions}

LSG, PH and NK conceived and designed the experiments. HNF, ITPW, ANS, ANA, CU performed the study. LSG and NK involved to data interpretation and statistical analysis. LSG wrote the first draft of the manuscript. PH and NK critically revised the manuscript for intellectual content. All authors read and approved the final manuscript. PH, LSG and NK are guarantors of the paper.

\section{Funding}

This research received no specific grant from any funding agency in the public, commercial or not-for-profit sectors.

\section{Availability of data and materials}

All data generated or analyzed during this study are included in the results section in this article. However, identifying/confidential patient data should not be shared.

\section{Ethics approval and consent to participate}

The ethical clearance was approved by the Ethical Review Committee, Faculty of Medicine, General Sir John Kotelawala Defence University, Sri Lanka. Permissions were obtained from both Provincial Director of Health Services and Regional Director of Health Services at Gampaha area to conduct the study. All parents were informed that their participation was voluntary and the procedure used did not pose any potential risk and their identities will be kept strictly confidential. Informed written consent forms were taken from all participants who voluntary participated and all information was kept in confidence.

Consent for publication

Not applicable. 


\section{Competing interests}

The authors declare that they have no competing interests.

\section{Author details}

'Department of Nursing and Midwifery, Faculty of Allied Health Sciences, General Sir John Kotelawala Defence University, Colombo, Sri Lanka. 2Department of Medical Laboratory Sciences, Faculty of Health Sciences, The Open University of Sri Lanka, Colombo, Sri Lanka. ${ }^{3}$ Department of Pre-Clinical Sciences, Faculty of Medicine, General Sir John Kotelawala Defence University, Colombo, Sri Lanka.

Received: 12 April 2019 Accepted: 10 June 2019

Published online: 18 June 2019

\section{References}

1. Leone A, Landini L, Leone A. What is tobacco smoke? Sociocultural dimensions of the association with cardiovascular risk. Curr Pharm Des. 2010;16:2510-7

2. Wilson LM, Tang EA, Chander G, Hutton HE, Odelola OA, Elf JL, et al. Impact of tobacco control interventions on smoking initiation, cessation, and prevalence: a systematic review. J Environ Public Health. 2012;2012:e961724.

3. Mukherjea A, Morgan PA, Snowden LR, Ling PM, Ivey SL. Social and cultural influences on tobacco-related health disparities among south Asians in the United States. Tob Control. 2012;21:422-8.

4. World Health Organization. WHO report on the global tobacco epidemic: WHO; 2015. URL http://www.who.int/tobacco/global_report/2015/report/ en/ (Accessed 1 Nov 2018)

5. Warren CW, Sinha DN, Lee J, Lea V, Jones NR. Tobacco use, exposure to second hand smoke, and training on cessation counseling among nursing students: cross-country data from the global health professions student survey (GHPSS), 2005-2009. Int J Environ Res Public Health. 2009;6:2534-49.

6. Guindon GE, Boisclair D. Past, current and future trends in tobacco use. Washington, DC: HNP discussion paper: World Bank; 2003. https:// openknowledge.worldbank.org/handle/10986/13726

7. Egbe CO, Peterson I, Weitz AM. Knowledge of the negative effects of cigarette smoking on health and well-being among southern Nigerian youth. Int J Soc Sci Humanity. 2016;6:184-90.

8. Warwick H, Alison D. Smoke: the killer in the kitchen; air pollution in developing countries: ITDG Publishing ISBN 185339588 9. 2004. Available at: https://www.humanitarianlibrary.org/sites/default/files/2014/07/ itdg\%20smoke\%20report.pdf.

9. Umberson D. Family status and health behaviors: social control as a dimension of social integration. J Health Soc Behavior. 1987:28:306-19.

10. Williams K, Umberson D. Marital status, marital transitions, and health: a gendered life course perspective. J Health Soc Behavior. 2004:45:81-98.

11. Umberson D. Gender, marital status and the social control of health behavior. Soc Sci Med. 1992;34:907-17.

12. Mayer O, Simon J, Heidrich J, Cokkinos D, De Bacquer D. Educational level and risk profile of cardiac patients in the EUROASPIRE II substudy. J Epidemiol Community Health. 2004:58:47-52.

13. Crone MR, Reijneveld SA, Willemsen MC, van Leerdam FJM, Spruijt RD, Sing RADH. Prevention of smoking in adolescents with lower education: a school based intervention study. J Epidemiol Community Health. 2003;57:675-80.

14. West $P$, Sweeting $H$, Young R. Smoking in Scottish youths: personal income, parental social class and the cost of smoking. Tob Control. 2007;16:329-35.

15. Laaksonen M, Rahkonen O, Karvonen S, Lahelma E. Socioeconomic status and smoking: analysing inequalities with multiple indicators. Eur J Public Health. 2005;15:262-9.

16. Koopmans JR, Slutske WS, Heath AC, Michael C, Neale MC, Boomsma DI. The genetics of smoking initiation and quantity smoked in Dutch adolescent and young adult twins. Behav Genet. 1999;29:383-93.

17. de Vries H. Socio-economic differences in smoking: Dutch adolescents' beliefs and behaviour. Soc Sci Med. 1995;41:419-24.

18. Wilkinson AV, Vasudevan V, Honn SE, Spitz MR, Chamberlain RM. Socio demographic characteristics, health beliefs, and the accuracy of cance knowledge. J Cancer Educ. 2009;24:58-64.

19. Kim SR, Kim OK, Yun KE, Khang YH, Cho HJ. Socioeconomic factors associated with initiating and quitting cigarette smoking among Korean men. Korean J Fam Med. 2009:30:415-25.
20. Leinsalu M, Tekkel M, Kunst AE. Social determinants of ever initiating smoking differ from those of quitting: a cross-sectional study in Estonia. Eur J Pub Health. 2007;17:572-8.

21. National Center for Chronic Disease Prevention and Health Promotion (US) Office on Smoking and Health. Preventing tobacco use among youth and young adults: a report of the surgeon general. Atlanta (GA): Centers for Disease Control and Prevention (US); 2012.

22. Lim HK, Ghazali SM, Kee CC, Lim KK, Chan YY, Teh HC, et al. Epidemiology of smoking among Malaysian adult males: prevalence and associated factors. BMC Public Health. 2013;13:8

23. Li W, Hsia J, Yang GH. Prevalence of smoking in China in 2010. N Engl J Med. 2011;364:2469-70.

24. Yidana A, Boakye-Yiadom A, Osei M. Tobacco use and its socio-cultural dimension among male adults in northern Ghana. Public Health Res. 2016;6:64-8.

25. Conrad KM, Flay BR, Hill D. Why children start smoking cigarettes: predictors of onset. British J Addict. 1992:87:1711-24.

26. Bhat M. Tobacco use and awareness patterns among students of an industrial training Institute in Mangalore, South India. Int J Biomed Res. 2014:5:368-70

27. Global Adult Tobacco Survey Collaborative Group, 2010a. Philippine's Country Reports. https://www.who.int/tobacco/surveillance/2009_gats_ report_philippines.pdf?ua=1. Accessed 5 Feb 2011

28. Global Adult Tobacco Survey: Thailand Country. Report http://www.searo. who.int/tobacco/surveillance/Global_Adult_Tobacco_Survey_Thailand_ Report 2011.pdf. Accessed 6 Feb 2012

29. Global Adult Tobacco Survey (GATS) India Report. 2009, https://www.who. int/tobacco/surveillance/en_tfi_india_gats fact_sheet.pdf. Accessed 5 Feb 2011), -2010

30. Global Adult Tobacco Survey: China Country report 2010. https://www.who. int/tobacco/surveillance/en_tfi_china_gats_factsheet_2010.pdf?ua=1. Accessed 6 Feb 2012.

31. Global Adult Tobacco Survey Collaborative Group, 2010b. Viet Nam's Country Reports. https://www.who.int/tobacco/surveillance/en_tfi_gats_ vietnam report.pdf?ua=1. Accessed 6 Feb 2012

32. Bader $P$, Boisclair D, Ferrence R. Effects of tobacco taxation and pricing on smoking behavior in high risk populations: a knowledge synthesis. Int J Environ Res Public Health. 2011;8:4118-39.

33. Gharaibeh H, Haddad L, Alzyoud S, El-Shahawy O, Baker NA, Umlauf M. Knowledge, attitudes, and behavior in avoiding second hand smoke exposure among non-smoking employed women with higher education in Jordan. Int J Environ Res Public Health. 2011:8:4207-19.

\section{Publisher's Note}

Springer Nature remains neutral with regard to jurisdictional claims in published maps and institutional affiliations.

Ready to submit your research? Choose BMC and benefit from:

- fast, convenient online submission

- thorough peer review by experienced researchers in your field

- rapid publication on acceptance

- support for research data, including large and complex data types

- gold Open Access which fosters wider collaboration and increased citations

- maximum visibility for your research: over $100 \mathrm{M}$ website views per year

At BMC, research is always in progress.

Learn more biomedcentral.com/submission 